\title{
KOMPETENCIAMODELL KIALAKÍTÁSA A BRIT KÖNYVTÁRI ÉS INFORMÁCIÓS SZAKEMBEREK SZÁMÁRA
}

\section{SIMON BERNEY-EDWARDS}

\section{Tartalmi összefoglaló}

A CILIP (Chartered Institute of Library and Information Professionals) a könyvtárosok, információs szakemberek és tudásmenedzserek vezetö szakmai szervezete. Tagjai számára egész pályafutásuk alatt gyakorlati támogatást nyújt, és felszólal a szakmai érdekek képviseletében. A tanulmány ismerteti a könyvtári és információs szakemberek kompetenciáinak fogalmát, a CILIP szakmai tudás- és készségbázisát, továbbá azt, hogy ez a bázis hogyan használható önértékelési eszközként. Bemutatja, hogy a tagok miként használhatják fel karrierjük fejlesztésére és arra, hogy tudásukat és készségeiket elismertessék, hogyan hasznosítják a könyvtárosképző intézmények az oktatásban, az egyes intézmények pedig munkatársaik fejlesztésében.

https://doi.org/10.46280/KOMPKONF.2020.Berney-Edwards

\section{Mi a kompetencia?}

Az Oxford English Dictionary meghatározása szerint a kompetencia (ha valaki kompetens) azt jelenti, hogy rendelkezik a szükséges képességekkel vagy tudással ahhoz, hogy valamit sikeresen elvégezzen, pontosabban - az egyéneket tekintve mindezt hatékonyan és hozzáértő módon teszi.

De miért fontos ez a könyvtári és információs szakemberek számára? Biztos, hogy csak könyveket kölcsönzünk? Hiszen bárki „ki tudja guglizni” a számára szükséges információt. Miért kell/ kéne kompetensnek lennünk?

Kedvelem ezt a 1921. évi újságkivágást (1. ábra), ami egy idézetet tartalmaz az Amerikai Könyvtáregyesület (American Library Association, ALA) elnökétől:

„A könyvtár sikere nem valamely rendszertöl függ, hanem azoknak a hatékonyságától és teljesitményétöl, akik irányítják." Valóban, a könyvtárak könyveket kölcsönöznek, és bárki végezhet információkeresést a Google segítségével, de mindez

LIBRARŶY MADE BY LIBRARIAN

Speaker at State Conference Says Institution Can' Rise No Higher Than Its Direotor.

[Speoial to The Indianapolis Star.] ArUNCIE, Ind., Oot. 20.-"The success of a trbrary does not dopend upon any syatem. but upon the ofmetonoy and aocomplishment of those who govorn ft," sald Dr, A. 8. Root of Oberlin, O. prosident of the Amorlean Llbrary ABsoolation, addressing tho thirtloth annual conforence of the Indiana Llbrary Assoclation at the opening meoting liero today. "For that ronson overy effort should bo put forth to intercat pooplo in taking up library work and then to soo that thoy hnve tho propor erally. will go to no grentor gonl than Boneral convlotions and enthusiasm slould be to mako his profosston atnnd up as $n$ glorious, attractive and onriching IIfo, so that pooplo will aeples to nter it.".

The, L. S. (1921, Oct 27). LIRRARY MADE BY LIBRARIAM. Indianapolis Star 
korántsem reprezentálja, milyen készségekkel és tudással rendelkezik egy korszerü könyvtári és információs szakember. Alapjában véve tudjuk, melyek a legjobb módszerek a szolgáltatásaink alapját jelentő gyüjtemények és információforrások megtervezésére, megszervezésére, irányítására, tárolására, visszakeresésére, reklámozására és feltárására. És ami ennél is fontosabb, tudjuk, hogyan tegyük mindezt jobban bárki másnál.

De néha ezt nem értékeljük kellőképpen, pedig jó lenne. Szeretném, ha mindannyian elvégeznének egy kísérletet. Csak nézzék végig, amint valaki minden előképzettség nélkül keresést végez az interneten. Nézzék meg, hogy fogalmazza meg a keresést, és hogy milyen webhelyeket választ ki. Én megtettem, és igazán tanulságos volt. Igen, bárki képes a Google használatára. De mi tudjuk, hogyan lehet a legjobbat kihozni a keresőmotorokból, hogyan strukturáljuk a kereséseinket, és hogyan válasszuk ki a legrelevánsabb webes forrásokat.

Ahogy az internet folyamatosan bővül, és a keresőmotorok egyre több algoritmust alkalmaznak, hogy elvezessenek bennünket ahhoz, amit a legrelevánsabb tartalomnak tekintenek (miközben hihetetlen mennyiségü reklámpénzt is bevetnek), egyre nehezebb a HELYES információ felderítése.

A CILIP-nél épp mostanában fejeztünk be egy munkát, amely a képzett könyvtári és információs szakemberek értékét becsüli fel. A szakirodalom áttekintése során olyan kutatásokat és bizonyítékokat kerestünk, amelyekkel igazolható, hogy a képzett szakemberek valamilyen hatást gyakorolnak. Számos olyan eredményt sikerült találnunk, amelyet egy-egy képzett szakember elér, köztük a következőket:

- megtérülő beruházások,

- javuló képzés és olvasási szokások,

- a felsőoktatásban a hallgatók jobb megtartása,

- összefüggés a jobb klinikai döntéshozatallal, betegközpontú ellátás, és rövidebb kezelési időtartam.

Tehát: igen, a kompetens, képzett könyvtári és információs szakemberek nélkülözhetetlenek ahhoz, hogy a használók a lehető legjobb könyvtári és információs szolgáltatásokhoz jussanak hozzá, és intézményeink elérjék stratégiai céljaikat.

\section{Kompetenciakeretek}

A könyvtári és információs szakemberek számára sokféle kompetenciakeretet fogalmaztak már meg. Az Egyesült Királyságban csak néhány, nagyon speciális keretrendszert találtunk. De van néhány nemzetközi keretrendszer is, amelyeket Önök is ismerhetnek, köztük az ausztrál és az amerikai könyvtáregyesületé, az IFLA normái és az amerikai szakkönyvtári egyesület (Special Library Association, SLA) által megfogalmazott alapvető kompetenciák.

De ezek közül több csak a szaktudás hagyományos területeire összpontosít. Meggyőződésünk, hogy ennél többre van szükség ahhoz, hogy valakiből sokoldalú szakember lehessen. 


\section{A CILIP gondolkodásmódja}

2011-ben a CILIP egy olyan projektre (Future Skills Project) adott megbízást, amely a jövőben szükséges szakmai készségekkel foglalkozott. Az volt a cél, hogy teljességgel áttekintsük, milyen készségeket kínálunk. Mindez a következő eredményeket hozta: Az új keretrendszert kilenc hónap alatt sikerült létrehozni, számos módszert felhasználva, többek között a következőket:

- módosult a felsőoktatási és szakmai képzettségek akkreditálásának folyamata,

- relevánsabbá vált és frissült a tagok szakmai regisztrációjával kapcsolatos ügymenet,

- létrehoztuk a CILIP virtuális tanulási rendszerét,

- új kompetenciakeretet alakítottunk ki a könyvtári, információs és tudással foglalkozó szakemberek számára.

Az új keretrendszert kilenc hónap alatt sikerült létrehozni, számos módszert felhasználva, többek között a következőket:

- felméréséket és konzultációkat bonyolítottunk le a tagokkal, a nem tagokkal, egyetemekkel, munkaadókkal és más kulcsszereplőkkel,

- létrehoztunk egy munkáltatói panelt, amely összefogja a legfontosabb munkaadókat a szakma egészéből,

- a projekt testülete olyan fejlesztési munkát végzett, amely szintén összefogta a különböző szektorok képviselőit,

- a City University közreműködésével ellenőriztük a szakemberek egészségét a felsőoktatásban,

- és a team sokféle nehéz feladatot végzett el, amely a tudás- és készségfajták meghatározásainak finomítására irányult.

A 2. ábra bemutatja a CILIP szakmaitudás- és készségbázisát, a PKSB-t (Professional Knowledge and Skills Base).

A PKSB azt a széles körü tudást és azokat a készségeket vázolja fel, amelyekre meggyőződésünk szerint szükség van, ha valaki a könyvtári és információs szakmában kíván dolgozni. Meggyőződésünk, hogy a tudásnak és készségeknek ez az együttese teszi szakmánkat egyedivé.

A PKSB-ben központi helyen szerepel az etika és az értékválasztás kérdése, mivel ezek alapozzák meg a szakmában a gyakorlatban dolgozók mindegyikének a tevékenységét. Ezután nyolc, a szakértelemmel és négy, általános készségekkel kapcsolatos területet határoztunk meg.

Az általános készségek szerepeltetése számottevő változást jelez a korábbi tudásbázishoz képest. Erre a munkaadók észrevételei alapján került sor. Arra mutattak rá, és nekünk is meggyőződésünkké vált, hogy a korszerü könyvtári és információs szakembernek fejlesztenie kell ezeket az általános készségeit, ha sikeres szeretne lenni a munkahelyén. 


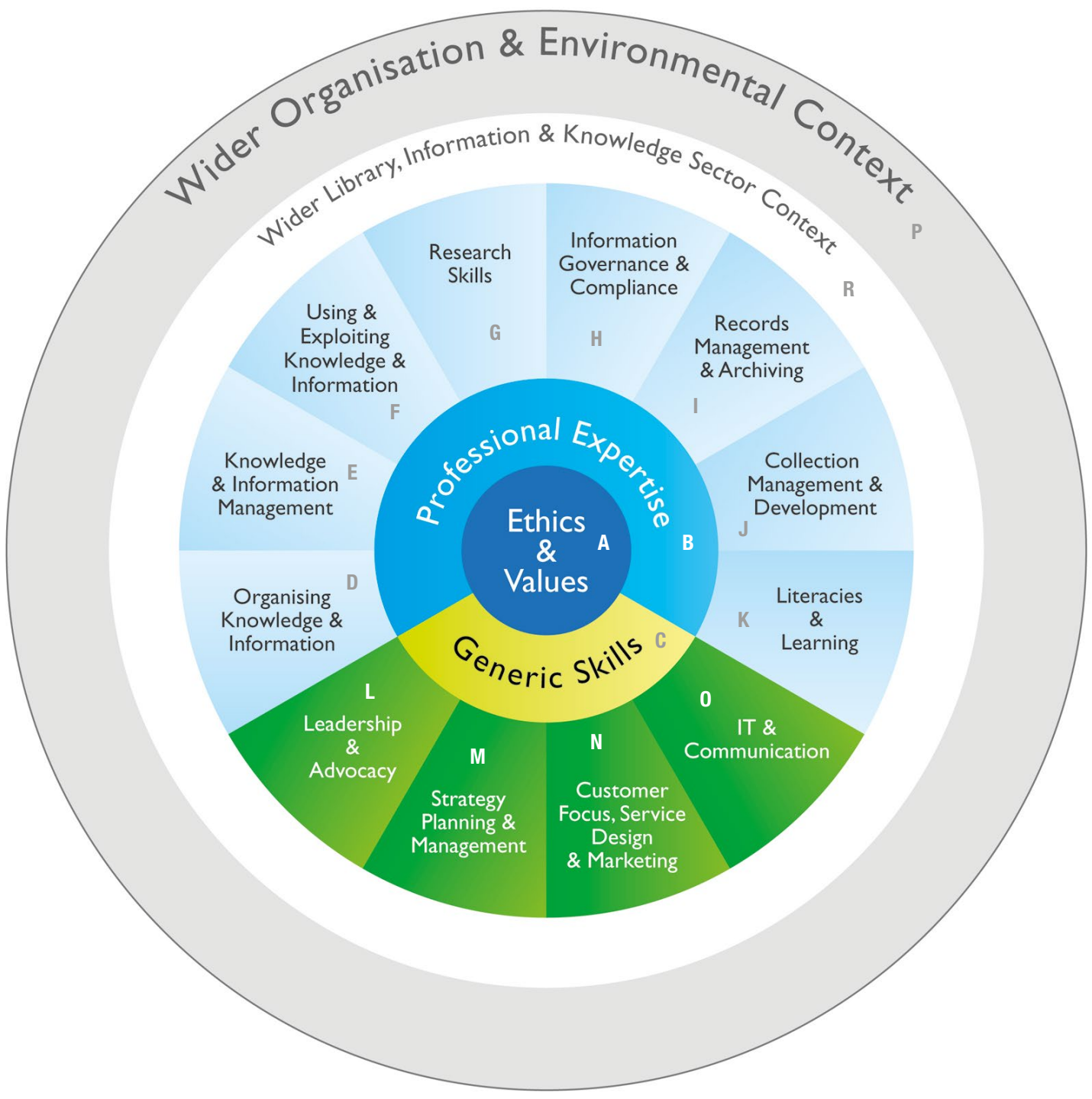

2. ábra: A CILIP szakmaitudás- és készségbázisa (PKSB)

A Etika és értékek

B Szakmai tapasztalatok

C Általános készségek

D Tudás- és információszervezés

E Tudás-és információmenedzsment

F A tudás és információ felhasználása és kiaknázása

G Kutatási készségek

H Információirányítás és megfelelőség

I Nyilvántartások kezelése és archiválás

J Gyújteménykezelés és -fejlesztés
K Múveltségek és tanulás

L Vezetés és érdekérvényesítés

M Stratégiai tervezés és menedzsment

N Használóközpontúság, szolgáltatástervezés és - marketing

0 Információtechnológia és kommunikáció

P Tágabb összefüggés a könyvtári, információs és tudásszektorral

R Tágabb szervezeti és környezeti összefüggés 
A szakértelmet és az általános készségeket a tágabb könyvtári, információs és tudásszektor összefüggései közé helyeztük, mert fontos tudnunk, hogy mi zajlik a szélesebb szakmán belül, és hogy hogyan tudunk egymástól tanulni.

Végezetül a tágabb szervezeti és környezeti összefüggésekről: rendkívül fontos, hogy megértsük tágabb intézményeink stratégiai irányultságát és a környezet összefüggéseit, ha biztosítani kívánjuk az általunk nyújtott szolgáltatások folyamatos fejlesztését és javítását.

Minden egyes itt szereplő átfogó terület (D-O) további hat-tíz tudás- és készségterületre bontható fel, ezt a következőkben röviden be is mutatom.

\section{4. Önértékelés}

A PKSB az önértékelés eszköze, amelyhez értékelési kritériumokat alakítottunk ki. Jelenleg online eszközként a CILIP-tagok számára a CILIP honlapján érhető el.

Igen fontos, hogy önértékelésről van szó. A CILIP nem kér bizonyítékot arra nézve, hogy tagjai elértek egy bizonyos színvonalat. Ez az eszköz a tagok számára ahhoz ad segítséget, hogy tudásuk és készségeik szintjét megítéljék, és megvizsgálják, hol szeretnének javítani.

Nem arról van szó, ki milyen szintet képvisel. Ez bizonyos fokig irreleváns. Az a fontos, hogy meghatározzuk azokat a területeket, amelyeken egy-egy szakember szeretné vagy szükségesnek-tartja tudása és készségei szintjének növelését, és elgondolkozzon rajta.

Ennek az eszköznek egy oldala a következőképpen fest (3. ábra):

\section{Szakértelem}

\section{Tudás- és információszervezés}

Mindenfajta tudás, információ és egyéb források szervezése, köztük különböző eszközök, stratégiák és protokollok kifejlesztése, és e források hatékony szervezése, keresése és visszakeresése. Ide tartozik a katalogizálás és osztályozás, a metaadatok és tézauruszok, a tárgyi feltárás és az adatbázis-tervezés.

\begin{tabular}{|c|c|c|c|}
\hline Tudás-/Készségterületek & $\begin{array}{l}\text { Jelenlegi } \\
\text { értékelés }\end{array}$ & $\begin{array}{c}\text { Ideális } \\
\text { értékelés }\end{array}$ & Észrevételek \\
\hline $\begin{array}{l}1.1 \text { Információs források } \\
\text { Az információ, a dokumentumok, elméletek } \\
\text { és modellek természetének megértése; } \\
\text { az információs források formái, és az } \\
\text { információszervezés következményei. }\end{array}$ & 2 & 2 & $\begin{array}{l}\text { Jelenleg is jól ismerem a terület alapfogalmait és elmélet } \\
\text { kérdéseit. Különös figyelmet fordítottam erre a területre, } \\
\text { mivel a CILIP-ben rám bízták az RDA-val kapcsolatos } \\
\text { munkálatok irányítását, ezért igyekeztem naprakészen } \\
\text { követni a jelenlegi gondolkodásmódot. }\end{array}$ \\
\hline $\begin{array}{l}\text { 1.2 Fájltervezés } \\
\text { A források elrendezése valamilyen módon egy } \\
\text { bizonyos igénynek megfelelően; beletartozik a } \\
\text { tudásforrások megtervezése. }\end{array}$ & 3 & 3 & $\begin{array}{l}\text { Az utóbbi néhány évben megterveztem és } \\
\text { megvalósítottam különböző fájltervezési rendszereket, } \\
\text { amelyekkel a CILIP projekt teamje meg tudta osztani és } \\
\text { fel tudta használni tudását. }\end{array}$ \\
\hline $\begin{array}{l}1.3 \text { Osztályozási rendszerek és taxonómiák } \\
\text { Tudásszervezési megoldások használata, amelyek } \\
\text { célja, hogy bemutassák a fogalmak közötti } \\
\text { kapcsolatokat, azáltal hogy egymáshoz rendelik a } \\
\text { hasonló jelentésű szakkifejezéseket. }\end{array}$ & 1 & 2 & $\begin{array}{l}\text { Jelenleg is ismerem az osztályozási rendszerek alapjait } \\
\text { - bár már sok év eltelt azóta, hogy magam feldolgoztam } \\
\text { vagy osztályoztam volna. } \\
\text { Mivel a vezetői tanács elnökeként múködöm, szeretném } \\
\text { bővíteni tudásomat az osztályozás és a taxonómiák } \\
\text { területén az RDA-val összefüggésben. }\end{array}$ \\
\hline
\end{tabular}


Amint látható, minden fejezet elején áttekintjük, hogy mi az adott terület tartalma. Ezt követően felsoroljuk, meghatározásokkal egyetemben, a különböző tudás- és készségterületeket. Ki-ki két oszlopot felhasználva értékelheti tudását és készségeit. Az első az aktuális értékelés, tehát az, hogy hol tart most. A második az ideális értékelés - ahová a jövőben szeretne eljutni.

Az „ideális” kifejezést használtuk, amely eléggé rugalmas ahhoz, hogy a CILIP-tagok különböző helyzetekben használni tudják, és meghatározzák maguk számára, hogy ez az ideális érték meddig juthat el, mondjuk, egy év alatt, egy bizonyos fejlesztési terv végére, tíz év múlva egy ideális munkakörre felkészítve...

Az észrevételekhez is biztosítunk teret, hogy a tagok megjelölhessék, miért alkalmaztak egy bizonyos értéket, vagy hétköznapibban megfogalmazva, miért szeretnének javulni, és mit kívánnak ezért tenni. Ezt különösen a regisztrációra jelentkező jelöltektől várjuk el.

A PKSB igen sokszínü, mivel a könyvtári és információs szakemberek széles köre számára készült, a köz- és iskolai könyvtárosoktól a kormányzatnál és az üzleti életben dolgozó, helyszíni információs és tudásmenedzserekig. Összesen 99 egyedi tudás- és készségterület áll rendelkezésre. Nincs olyan elvárás, hogy mindenkinek mindenben szakértőnek kell lennie. A CILIP szerint az egyes emberek tudásának és készségeinek szintje az adott ágazattól, intézménytől és az abban betöltött feladatkörtől függ. Megfigyelhető az is, hogy amikor két szakember ugyanazt a feladatkört tölti be, tudásukat és készségeiket tekintve eltérő követelményeknek kell megfelelniük, feladatkörük speciális követelményei alapján, illetve arra alapozva, hogy a vezetők igyekeznek az illető szakemberek erősségeit kihasználni.

A példa, amelyet közöltem, a saját PKSB értékelésemből való, és láthatják, hogy miközben megtartottam alapfokú tudásomat az osztályozás és a taxonómiák területén, felismertem, hogy szeretnék javulni ezen a területen, mivel szerepet kaptam az RDA fejlesztésében. Azért is mutatom ezt be, mert ez az egyik terület, ahol nem kaptam jó osztályzatot. De ez nem számít. Ez már nem fontos a feladatköröm szempontjából. Ahol magasabb osztályzatot kapok, az az általános készségek területe - például az irányítás, a vezetés, a projektek és a változások kezelése - mert jelenleg itt tartok a karrieremben.

\section{A javítandó területek megállapítása}

Amikor a tagok megállapítják, hol vannak hiányosságaik, megkérjük őket, gondolják át, hogy miképpen kívánják ezeket behozni szakmai továbbképzéssel. Nem feltétlenül gondolunk valamilyen kurzusra. Arra bátorítjuk tagjainkat, hogy vegyék igénybe a tudásuk és készségeik fejlesztésére a rendelkezésre álló lehetőségek széles körét. A kurzusokon kívül lehet szó valamilyen szakmai összejövetelről, szakmai vitákba való bekapcsolódásról, a szakirodalom olvasásáról vagy valamely intézmény meglátogatásáról.

A CILIP arra törekszik, hogy a könyvtári és információs szakemberek alaposan gondolják át, milyen fejlesztést igényelnek, és keressék meg, hogy ezt az igényt miképpen lehet a 
legjobban kielégíteni. Ez rendkívül fontos ahhoz, hogy a tanulás eredményes legyen és alkalmazható legyen a feladatkör ellátásában.

Azon tagjaink számára, akik tudásszintjük emeléséhez javaslatokat várnak, olyan forrásokat nyújtunk, amelyek támogatást adnak a választáshoz.

Virtuális tanulási környezetünkben külön fejezet foglalkozik a PKSB-vel. Szerepelnek benne a következők:

- online képzési tartalom (például webináriumok és rövid online kurzusok felvételei),

- könyvek a Facet kiadótól,

- speciális csoportok.

Az egyes területekhez olyan sablonokat is adunk, amelyet segítenek átlátni, hogy az egyes szektorokban milyen tudásra és készségekre lehet szükség. Ezek különösen hasznosak lehetnek a pályakezdők számára vagy azoknak, akik a szakma más területén keresnek elhelyezkedési lehetőséget.

\section{A PKSB használata: tagok}

A CILIP mint Királyi Oklevéllel (Royal Charter) rendelkező szervezet elvégezheti azoknak a szakmai regisztrációját és elismerését, akik bizonyítékot szolgáltatnak arra nézve, hogy rendelkeznek a feladataik ellátásához szükséges tudással, készségekkel és képességekkel. Mindez három szinten valósul meg, ezek: bizonyítvány, oklevél és Fellow-cím.

- A bizonyítvány az olvasók szolgálatában dolgozók számára szól, akik szeretnék elismertetni a gyakorlati munka során megszerzett tudásukat és készségeiket.

- Az oklevelet azok kaphatják, akik szakmai feladatkörben dolgoznak.

- A Fellow-cím a szenior munkakörben dolgozó tapasztalt szakembereknek szól, illetve azoknak, akik jelentősen hozzájárultak a szakma fejlődéséhez.

A szakmai regisztráció lényeges része a PKSB szerint elvégzett értékelés és annak felhasználása egy fejlődési terv elkészítéséhez.

A tagok ahhoz is hasznosnak találták a PKSB-t, hogy új állást találjanak. Az egyik, speciális érdeklődésủ csoportnak szóló folyóiratban Katie Treherne megírta, hogyan lett jogi szakkönyvtárosból egészségügyi szakkönyvtáros. A PKSB-t használta ahhoz, hogy olyan területeken fejlödjön, amelyekről úgy látta, hogy az új feladatkörben szükségesek lehetnek.

Tudjuk, hogy tagjaink értékelték magát a PKSB-t, és az eredményeket megosztották vezetőikkel és munkaadóikkal. Ez különösen hasznosnak bizonyult abban az esetben, amikor az illető az egyetlen könyvtári-információs szakember az intézményben, mivel így lehetősége nyílik arra, hogy megismertesse munkáltatójával, hogy milyen egyedi készségekkel rendelkezik, és azzal, hogy ez milyen előnyt és értéket jelent az intézmény számára. 


\section{A PKSB használata: tanulási szolgáltatók}

Az egyetemeknek a PKSB-t kell használniuk, amikor a CILIP-nél akkreditációra pályáznak. A tanulási szolgáltatókat arra kérjük, hogy kurzusaikat vessék össze a PKSB-vel, hogy értékelhessük, mennyire releváns a kurzus a szakma számára.

A CILIP-nél való akkreditációhoz a kurzusoknak be kell mutatniuk, hogy tartalmazzák a PKSB tartalmának egy bizonyos százalékát (a kurzus szintje alapján).

Ez az értékelés - a szolgáltatásminőség értékelésével, a munkáltatók bevonásával és az oktatók fejlődésével párosítva - azt jelenti, hogy a potenciális hallgatók számára garantálni tudjuk, hogy egy akkreditált kurzus felkészíti őket a szakma gyakorlati művelésére.

Egy nemrégiben megjelent interjúban a skóciai Robert Gordon Egyetem úgy nyilatkozott, hogy az, hogy a PKSB-t használták, amikor nemrégiben a CILIP-nél akkreditáltatták magukat, és ezzel lehetővé vált számukra, hogy hangsúlyozzák, kurzusaik mennyire az egyes tudományterületekkel kapcsolatos speciális és a más területen is alkalmazható készségekre összpontosítanak.

Emellett egyes egyetemek a PKSB-t oktatási anyagként is elkezdték használni.

A londoni University College arra kéri összes hallgatóját, hogy végezzék el az értékelést a PKSB-vel a kurzus elején és végén, hogy felmérjék, mennyire fejlődtek készségeik.

\section{A PKSB használata: munkaadók}

Számos munkáltatóval müködtünk együtt, akik örömmel alkalmazták a PKSB-t munkatársaik fejlesztésének eszközeként. A legfigyelemreméltóbb példa a Honvédelmi Minisztériumé (Ministry of Defence). Olyan tananyagot alakítottak ki a személyzet számára, amely arra ad példákat, hogy az egyes készségek speciálisan hogyan viszonyulnak ahhoz a feladatkörhöz, amelyet egy kormányzati intézménynél töltenek be.

Ezután a PKSB-ben meghatározták az „ideális” besorolást a munkatársak számára az intézmény minden szintjén. Ezt követően kérték meg a személyzet minden tagját, hogy végezze el az értékelést.

Így tudták meghatározni a válaszok alapján, hogy az intézménynél hol jelentkeztek hiányosságok a tudásban és a készségekben, majd ezt felhasználva új személyzeti képzési és fejlesztési tervet fogalmaztak meg.

Dolgoztunk a Health Education England elnevezésü, egészségügyi képzéssel foglalkozó szervezettel is, amely az egészségügyben dolgozó valamennyi információs szakemberért felelős, és kialakítottuk a PKSB speciális változatát az egészségügyi szektorból vett példákra alapozva. 


\section{A PKSB elérhetősége}

További információk a PKSB-ről a CILIP weboldalán: www.cilip.org.uk/pksb. A teljes önértékelési eszköz csak a tagoknak áll rendelkezésükre.

\section{Irodalom}

BRETTLE, Alison - MADEN, Michelle: What evidence is there to support the employment of trained and professionally registered library, information and knowledge workers? A systematic scoping review of the evidence. London, CILIP, 2015. [87 p.]Forrás: https://archive.cilip.org.uk/sites/default/ files/documents/value_of_trained_lik_workers_final_211215.pdf [2018. október 31.]

TREHERNE, Katie: Switching sectors and professional development. A personal experience = CLSIG Journal, 11. July, 2015. 6-8. p. Forrás: https://archive.cilip.org.uk/sites/default/files/documents/clsig_ journal_no_11_july_2105.pdf [2018. október 31.]

Simon Berney-Edwards a brit könyvtári és információs szakemberek egyesületének (The Chartered Institute of Library and Information Professionals, CILIP) igazgatója. Nemzeti, regionális és helyi szinten is jelentős szakmai tapasztalatokkal rendelkező vezető. Szakterületei: érdekképviselet, partnerségi munkavégzés, projekt- és változásmenedzsment, tárgyalási stratégiák és pénzügyi tervezés, a szolgáltatások fejlesztése. Feladatai közé tartozik a CILIPtagok továbbképzésének és a végzettségek elismerésének támogatása. Az általa vezetett igazgatósághoz tartoznak az akkreditáció, a továbbképzés kérdései és a Facet kiadó is. 